\title{
IN VITRO EVALUATION OF CYTOTOXIC AND GENOTOXIC EFFECTS OF PLANT EXTRACTS FROM NOTHAPODYTES FOETIDA (WIGHT) SLEUMER (FAMILY: ICACINACEAE)
}

\author{
KAILAS D DATKHILE*, PRATIK P DURGAWALE, MADHAVI N PATIL
}

Department of Molecular Biology and Genetics, Molecular and Genetic Laboratory, Krishna Institute of Medical Sciences University, Satara, Maharashtra, India. Email: hodgeneticslab@kimsuniversity.in

Received: 25 June 2018, Revised and Accepted: 02 August 2018

\section{ABSTRACT}

Objective: The objective of this study is to investigate cytotoxic and genotoxic properties of aqueous and methanolic extracts of the aerial parts of Nothapodytes foetida (Wight) Sleumer plant.

Methods: The cytotoxic effects of aqueous and methanol extract of leaves and stem bark on cell viability of HeLa, MCF7, and HCT-15 cell lines was determined by 3-(4,5-dimethylthiazol-2yl)-2,5-diphenyltetrazoliumbromide assay. We also confirmed the genotoxic effects of plant extracts through DNA fragmentation in cancer cells and expression pattern of apoptotic genes including p53 and caspase-3 analyzed by semiquantitative reverse transcription-polymerase chain reaction and western blotting techniques.

Results: The present study revealed that, when plant extract was tested for cytotoxic activity, the data obtained from cell viability results of HeLa and MCF7 cells revealed that methanol extract of leaves and stem bark exhibited a range of significant cytotoxic activities in a dose-dependent manner varying from 2.5 to $25 \mu \mathrm{g} / \mathrm{mL}$, whereas an aqueous extract of leaves and stem bark showed decreased cell viability with an increase in the concentration of both the extracts from 5 to $50 \mu \mathrm{g} / \mathrm{mL}$.

Conclusion: These results indicated that the crude extract aerial parts of $N$. foetida plant contain promising substances having a potential as cytotoxic agent.

Keywords: Nothapodytes foetida, Cytotoxicity, Genotoxicity, Cell viability, Apoptosis.

(C) 2018 The Authors. Published by Innovare Academic Sciences Pvt Ltd. This is an open access article under the CC BY license (http://creativecommons. org/licenses/by/4. 0/) DOI: http://dx.doi.org/10.22159/ajpcr.2018.v11i12.28087

\section{INTRODUCTION}

Natural products from medicinal plants play a significant role in drug discovery and development of an alternative and complementary method for therapeutics of various deadly diseases including cancer. The number of strategies has been implemented to combat against such fatal diseases. Chemotherapy is one of the commonly used treatments in routine practice but with unsatisfactory outcome due to the problem of hazardous side effects and toxicity to normal cells. Therefore, in recent years, researchers all over the world are trying to explore the therapeutic potential of medicinal plants and their phytoconstituents to conquer the circumstances. Naturally occurring phytochemicals from medicinal plants contain a wide range of secondary metabolites with remedial properties [1,2] which have acquired substantial contribution in curing of dreadful diseases. At this moment, $>35,000$ plant species have been reported to be used globally for medical purposes where $60 \%$ of currently used therapeutic drugs have been isolated from natural products of $>3000$ plants worldwide [1]. In Indian subcontinent, a number of medicinal plants are conventionally utilized as a part of regular diet and are also being used as traditional medicine to treat various diseases. Despite the extensive use, relatively small number of plants has been accepted by scientific community; however, systematic evaluations of most of these medicinal plants for their therapeutic properties are missing.

The defensive mechanism of natural phytochemicals from medicinal plants is thought to be because of increased antioxidants, antiinflammatory, antiproliferative, and apoptotic effects [3-5]. Nothapodytes is a medicinally important plant showing the presence of secondary metabolites such as al alkaloid, glycosides, and flavonoids linearly distributedin plant parts such as leaves, stem bark, roots, and fruits [6,7]. Earlier reports on phytochemicals and their pharmacological activities of Nothapodytes nimmoniana showed the presence of camptothecin as an alkaloid in different plant parts [8]. 9-methoxy camptothecin is also characterized from Nothapodytes foetida [9] which showed anticancer activity [10]. Previously, a report on camptothecin derived from leaves, bark, and stem bark showed effective action against breast cancer cell line [11]. Although earlier studies reported anticancer properties of active phytoconstituents from Nothapodytes spp., there are no previous studies either on cytotoxicity or genotoxicity of $N$. foetida extract.

Therefore, based on the analysis of published literature, we selected traditional endangered plant with medicinal value, Mapia foetida commonly known as Amruta, now renamed as $N$. foetida (Wight) Sleumer (Synonym: N. nimmoniana [Family: Icacinaceae]) to evaluate its cytotoxic and genotoxic value. As this medicinal plant possess antibacterial, antiparasitic, antiseptic, carminative, diuretic, and purgative properties, this plant had been used traditionally for a long time as substitutional medicine to treat a variety of diseases including abdomen complaints, nervous and sporadic weakness, respiratory disorders, and menstrual complaints [12-15]. Recent pharmacological investigations demonstrated antibacterial and anti-inflammatory activities of the root extracts of $N$. nimmoniana species [16] as well as free radical scavenging and antioxidant properties of different plant parts of $N$. foetida [17], but the detailed documented information on its molecular aspects involved in cytotoxic and genotoxic activity remained unexplored and undisclosed till date. The present study was aimed to determine the inhibitory effects of crude extract of plant parts including leaves and stem bark of $\mathrm{N}$. foetida on cell proliferation and to explore the fate of cell death in response to crude extract exposure. Therefore, in order to study the cytotoxic and genotoxic effects of N. foetida extracts, we used different cancer cell lines including HeLa, (human cervical carcinoma cells), MCF7 (human breast carcinoma cells), and HCT-15 
(human colon adenocarcinoma cells). The plausible cytotoxic effect of plant extracts was tested against cell lines by 3-(4,5-dimethylthiazol2yl)-2,5-diphenyltetrazoliumbromide (MTT) assay, as well as the possible genotoxic effect was attempted through DNA fragmentation assay. Along with, we also demonstrated the status of expression of apoptotic genes at mRNA and protein level by semiquantitative reverse transcription-polymerase chain reaction (RT-PCR) and western blotting, respectively.

\section{METHODS}

\section{Chemicals}

Minimum essential medium (10370-021), fetal bovine serum (FBS) (2614079), RPMI1640 (11875-085), penicillin-streptomycin (15140-122), and cDNA synthesis kit (AB-1453/B) were purchased from Thermo Fisher Scientific; dimethyl sulfoxide (DMSO) (D2650), camptothecin (C9911), and Rabbit polyclonal anti-caspase3 antibody (C9598) were purchased from Sigma Aldrich; nitrocellulose membrane (HATF00010) was purchased from Millipore; MTT (M6494) was purchased from Invitrogen; mouse monoclonal anti-p53 antibody (Ab26), goat anti-mouse IgG H and L HRP sec antibody (ab97040), goat anti-rabbit IgG H and L HRP sec antibody (Ab6721), and rabbit polyclonal anti-GAPDH antibody (Ab9485) were purchased from Abcam; 6 well plates (CLS3355), 96 well plates (CLS3599), and $5 \mathrm{~mL}$ sterile pipettes (CLS4487) were purchased from Corning and WesternBright $^{\mathrm{Tm}}$; and ECL western blot detection kit (K12045-D20) was purchased from Advansta.

\section{Collection and processing of plant materials}

Fresh leaves and stem bark of $N$. foetida were collected from forests of Amboli Ghat of south-western Maharashtra from India in December 2016. Identification and authentication of the plants were done at the Department of Botany, University of Pune. The plant parts were thoroughly washed with sterile distilled water to remove adhered dust particles, shade dried, and then ground into fine powder using mortar and pestle. The powdered samples were stored in an airtight container in the dark at room temperature for further experiments.

\section{Preparation of aqueous plant extract}

To prepare aqueous extract, $100 \mathrm{~g}$ dried powder of leaves and stem bark was mixed with $1000 \mathrm{~mL}$ of double-distilled water in a round bottom flask and allowed to Soxhlet extraction. The mixture was boiled at $80^{\circ} \mathrm{C}$ in Soxhlet apparatus. After ten cycles of soxhlation, the aqueous extract with $90 \%$ yield was evaporated through at $55^{\circ} \mathrm{C}$, and the dried powder was stored in airtight container. Aqueous extract was prepared by dissolving $10 \mathrm{mg}$ of dried powder in $1 \mathrm{~mL}$ of sterile distilled water and finally filtered through $0.22 \mu \mathrm{m}$ filter and stored in a refrigerator at $2-8^{\circ} \mathrm{C}$ until used for further experiments.

\section{Preparation of methanol plant extract}

The methanol extract of different dried plant parts was prepared by soxhlation. In this extraction process, $100 \mathrm{~g}$ of dried powder was extracted with $1000 \mathrm{~mL}$ of methanol at $70^{\circ} \mathrm{C}$ temperature for ten extraction cycles. All the resulting extracts with $100 \%$ yield were transferred to crucible dishes kept in desiccators to evaporate the liquid solvent from the extract to get dry powder. The methanol extract was further prepared by dissolving $10 \mathrm{mg}$ of dried powder in $1 \mathrm{~mL}$ of methanol and used for further experiments.

\section{In vitro evaluation of cytotoxicity properties of $\mathrm{N}$. foetida plant extract}

\section{Cell lines and cell culture}

To investigate cytotoxic effects of the aqueous as well as methanol extracts of $N$. foetida leaves and stem bark in vitro, HeLa, MCF7, and HCT-15 cell lines were procured from the National Centerf for Cell Sciences Pune, India. The HeLa and MCF7 cells were maintained in T-25 flasks containing MEM essential media, whereas HCT-15 cells were maintained in RPMI1640 media along with 10\% heat-inactivated FBS and penicillin-streptomycin at $100 \mathrm{U} / \mathrm{mL}$ and $100 \mu \mathrm{g} / \mathrm{mL}$, respectively.
Cells were maintained under an atmosphere of $5 \% \mathrm{CO}_{2}, 95 \%$ humidity, and $37^{\circ} \mathrm{C}$ temperature.

\section{In vitro cytotoxicity assay}

In vitro cytotoxicity effects of the aqueous and methanol extracts of N. foetida leaves and stem bark on human cancer cell lines including HeLa, MCF7, and HCT-15 cells were determined by the MTT assay. The cells were maintained in MEM as well as RPMI1640 medium supplemented with $10 \%$ FBS, penicillin-streptomycin at $100 \mathrm{U} / \mathrm{mL} / 100 \mu \mathrm{g} / \mathrm{mL}$ in a humidified atmosphere of $5 \% \mathrm{CO}_{2}$ at $37^{\circ} \mathrm{C}$. About 10,000 cells in the respective medium were seeded in a 96-well plate and incubated at $37^{\circ} \mathrm{C}, 5 \% \mathrm{CO}_{2}$. After $24 \mathrm{~h}$ incubation, the confluent cells were exposed to respective treatment of methanol extract at concentrations of 2.5, 5, $7.5,10,15,20$, and $25 \mu \mathrm{g} / \mathrm{mL}$ (leaves and stem bark) as well as aqueous extracts at concentrations of $5,10,20,30,40$, and $50 \mu \mathrm{g} / \mathrm{mL}$ in culture medium without FBS and incubated for further $48 \mathrm{~h}$ at $37^{\circ} \mathrm{C}$ and $5 \%$ $\mathrm{CO}_{2}$. After $48 \mathrm{~h}$ completion of treatment, cells were washed with sterile phosphate-buffered saline, thereafter cell viability was determined using MTT dye. $10 \mu \mathrm{l} /$ well of MTT ( $5 \mathrm{mg} / \mathrm{mL}$ ) added to the cells, and the plates were further incubated $37^{\circ} \mathrm{C}, 5 \% \mathrm{CO}_{2}$ atmosphere. After $4 \mathrm{~h}$ incubation, the MTT solution was carefully removed and $200 \mu \mathrm{l}$ of DMSO was added to each well. The absorbance of purple color developed was measured at $560 \mathrm{~nm}$ wavelength using ultraviolet (UV)-visible 1800 spectrophotometer (Shimadzu). The results were expressed as a percentage of cell survival as compared to the control. All experiments were performed in triplicates.

\section{Cell morphology}

Cells $\left(1 \times 10^{6}\right.$ cells/well) were seeded in a six-well culture plate and incubated for $24 \mathrm{~h}$ at $37^{\circ} \mathrm{C}$ in $5 \% \mathrm{CO}_{2}$. Later, the cells were treated with $2.5,5,7.5,10,15,20$, and $25 \mu \mathrm{g} / \mathrm{mL}$ concentrations of the methanol extract of $N$. foetida leaves and stem bark as well as 5, 10, 20, 30, 40, and $50 \mu \mathrm{g} / \mathrm{mL}$ of aqueous extract (leaves and stem bark) in respective culture medium without FBS and further incubated for $48 \mathrm{~h}$. The morphology of the cells was then examined in an inverted phasecontrast microscope (Primovert Carl Zeiss microscope).

\section{DNA fragmentation assay}

The apoptotic activity of the methanol as well as aqueous extract of leaves and stem bark of $N$. foetida was determined by DNA fragmentation assay. HeLa, MCF7, and HCT-15 cells $\left(1 \times 10^{6}\right)$ in 6 well plates were treated with $50 \%$ inhibitory concentration (IC) and $\mathrm{IC}_{90}$ concentrations of methanol as well as aqueous extract along with untreated control cells and incubated at $37^{\circ} \mathrm{C}$ in $5 \% \mathrm{CO}_{2}$, for $48 \mathrm{~h}$. Cells were harvested, followed by lysis in $0.3 \mathrm{~mL}$ of cell lysis buffer containing (10 mM Tris-HCl, pH 7.5, 1 mM EDTA, 0.2\% triton X-100, $0.5 \%$ sodium dodecyl sulfate (SDS). After treatment with $0.5 \mathrm{mg} / \mathrm{mL}$ of Ribonuclease $\mathrm{A}$ at $37^{\circ} \mathrm{C}$ for $1 \mathrm{~h}$, thereafter, $0.2 \mathrm{mg} / \mathrm{mL}$ of Proteinase- $\mathrm{K}$ at $55^{\circ} \mathrm{C}$ for $1 \mathrm{~h}$, DNA was precipitated by addition of equal volume of isopropanol and $1 / 10^{\text {th }}$ volume of 5 Molar (M) sodium chloride. The DNA pellet was resuspended in Tris-EDTA buffer and DNA was separated on $1.5 \%(\mathrm{w} / \mathrm{v}$ ) low EEO agarose (GeNei) gel containing 1 $\mu \mathrm{g} / \mathrm{mL}$ ethidium bromide and subjected to electrophoresis at 80 volts (V) for 1-2 $\mathrm{h}$ in Tris-Acetate-EDTA buffer along with 100 base pair (bp) and 1 kilo bp (Kb) DNA molecular weight marker. The DNA fragments were visualized by exposing the gels to UV transilluminator followed by photography in gel documentation system (BioRad Laboratories, USA).

\section{Semiquantitative RT-PCR}

Relative expression of apoptotic genes including p53 and caspase-3 was measured by semiquantitative RT-PCR performed as per the method described earlier by Datkhile et al. 2017 [18]. HeLa, MCF7, and HCT-15 cells $\left(1 \times 10^{6}\right)$ were treated at $\mathrm{IC}_{50}$ concentration of methanol extract of $N$. foetida for $48 \mathrm{~h}$. RT-PCR was performed using cDNA prepared from treated as well as control cells using primers: p53 FP 5'-actaagcgagcactgcccaa-3', p53 RP 5'-atggcgggaggtagactgac-3', caspase-3 FP 5'-gtggcattgagacagacagtgg-3', caspadse-3 RP $\quad 5^{\prime}$-gccaagaataataaccaggtgc-3', GAPDH $\quad$ FP 
5'-acccactcctccacctttg-3', and GAPDH RP5'-ctcttgtgctcttgctggg-3' to obtain amplification of p53, caspase3, and GAPDH (housekeeping) gene, respectively. Following 35 cycles of PCR amplification at $\left(94^{\circ} \mathrm{C}\right.$ for $30 \mathrm{~s}, 50^{\circ} \mathrm{C}$ for $30 \mathrm{~s}$, and $72^{\circ} \mathrm{C}$ for $\left.30 \mathrm{~s}\right)$, electrophoretic separation of PCR products was performed with $2.0 \%$ low EEO agarose gel in Tris-Borate EDTA buffer. Relative optical density of ethidium bromide stained amplicons was determined using image analysis software Image Lab 3.0 software (BioRad, USA).

\section{Western blotting}

$1 \times 10^{6} \mathrm{HeLa}$, MCF7, and HCT-15, control, and methanol extract treated cells in each well of 6 well plates were harvested and lysed in protein extraction buffer (50 mM Tris, 5 mM EDTA, 0.1\% Triton-X100, 1 mM PMSF, $0.5 \mathrm{mM}$ DTT, and protease inhibitor cocktail) and protein content was quantitated by the Bradford protein estimation method. $50 \mu \mathrm{g}$ protein of each cell was resolved on 10\% SDS-PAGE followed by transfer onto a nitrocellulose membrane. Subsequently, membranes were probed with rabbit anti-caspase3 (1:1000), anti-GAPDH (1:5000), and mouse anti-p53 (1:2500) antibodies. Immunoreactive bands were visualized using WesternBright ${ }^{\mathrm{Tm}}$ ECL detection system.

\section{Statistical analysis}

The data of percentage cell viability were reported as mean \pm standard error of mean of three independent experiments. Student's t-test was performed to examine the significant differences between quantitative data of means of expression levels of mRNA as well as protein from control and plant extract treated samples. $\mathrm{p}<0.001$ was considered as statistically significant.

\section{RESULTS AND DISCUSSION}

In the present study, we elaborated cytotoxic and genotoxic properties of one of the medicinally important plants $N$. foetida with plant parts including leaves and stem bark with methanol and aqueous extracts in vitro using human breast, cervix, and colon cancer cell lines. A dosedependent cytotoxic activity was observed in both methanol and aqueous extracts of leaves and stem bark of $N$. foetida in HeLa, MCF7, and HCT- 15 cells.

Primarily, to screen in vitro cytotoxicity of methanol as well as aqueous extract of $N$. foetida leaves and stem bark, the cell viability was determined by MTT assay. The cytotoxic activity of both leaves and stem bark extracts on HeLa cells represented in figure (Fig. 1a and b), whereas the activity of both extracts on MCF7 cells showed in Figure 2a and b. When plant extract was tested for cytotoxic activity, the data obtained from cell viability results of HeLa and MCF7 cells revealed that methanol extract of leaves and stem bark exhibited a range of significant cytotoxic activities in a dose-dependent manner varying from 2.5 to $25 \mu \mathrm{g} / \mathrm{mL}$, whereas an aqueous extract of leaves and stem bark showed decreased cell viability with an increase in the concentration of both the extracts from 5 to $50 \mu \mathrm{g} / \mathrm{mL}$. Similarly, when the cytotoxic activity of leaves and stem bark on HCT-15 cells was examined, the results showed $20 \mu \mathrm{g} / \mathrm{mL}$ as a lethal concentration for methanol extract and $40 \mu \mathrm{g} /$ $\mathrm{mL}$ lethal concentration for aqueous extract of both leaves and stem bark (Fig. 3a and b). The results indicated that when HeLa and MCF7 cells were treated with $25 \mu \mathrm{g} / \mathrm{mL}$ concentration of methanol extract of both leaves and stem bark, both the cells showed 100\% mortality,

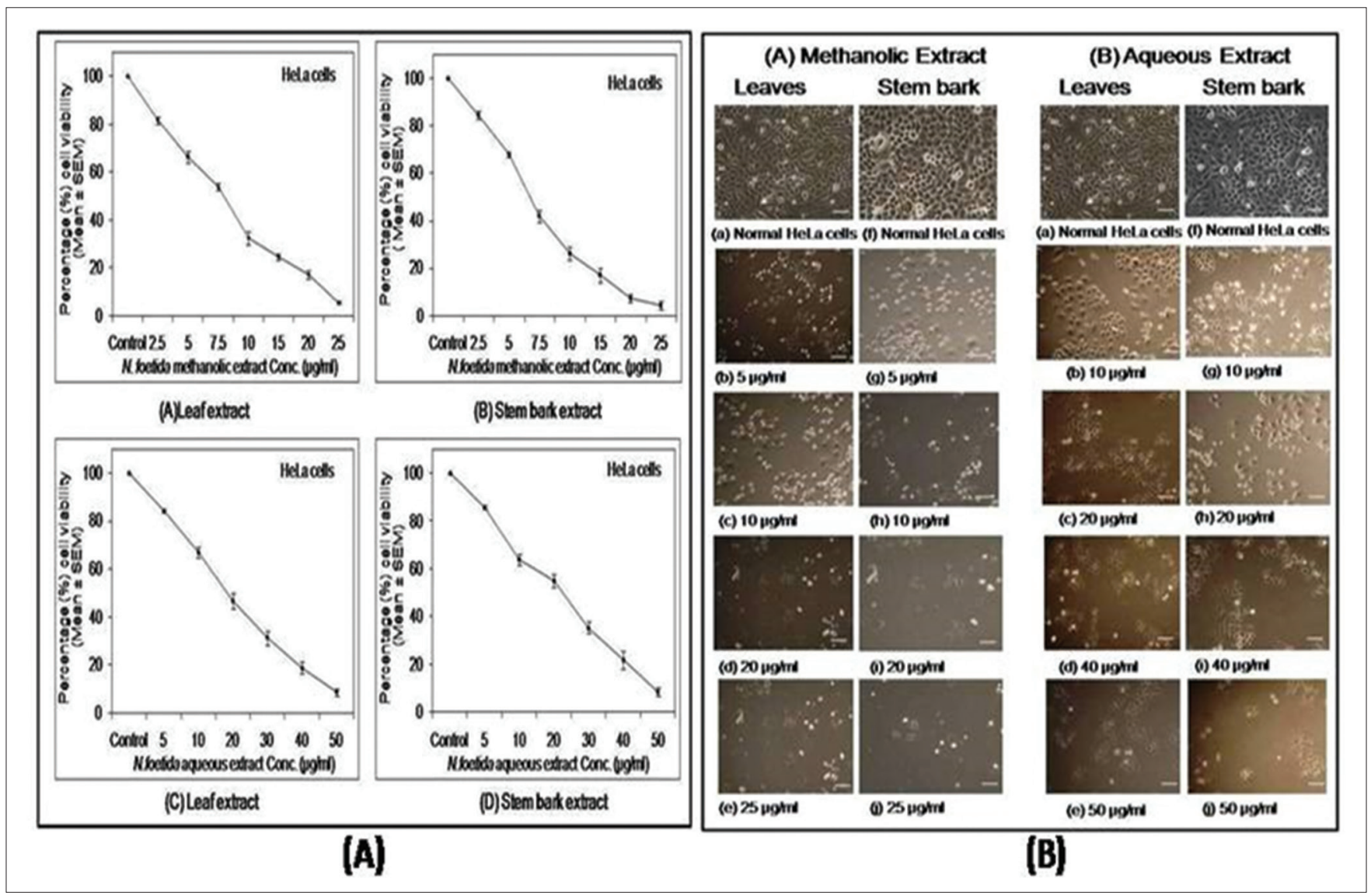

Fig. 1: (A) Representative histogram showing in vitro dose-dependent cytotoxicity of (A) Methanolic extract of leaf (B) Methanolic extract of stem bark (C) Aqueous extract of leaf (D) Aqueous extract of stem bark at different concentrations on HeLa cells. The results represent the means of three independent experiments, and error bars represent the standard error of the mean. (B) Cell morphology of HeLa cells after $48 \mathrm{~h}$ treatment of (A) Methanolic extract of leaves and stem bark of Nothapodytes foetida, at different concentrations (b, g) 5 , (c, h) 10, (d, i) 20 and (e, j) $25(\mu \mathrm{g} / \mathrm{mL})$, (B) Aqueous extract of leaves and stem bark at concentrations (b, g) 10, (c, h) 20, (d, i) 40, and $(e, j) 50(\mu \mathrm{g} / \mathrm{mL})$. In all panel first row of cells $(\mathrm{a}, \mathrm{f})$ are untreated control cells. All images are taken at $\times 20$ magnification with Carl Zeiss phase contrast microscope. Scale bars, $100 \mu \mathrm{m}$ 


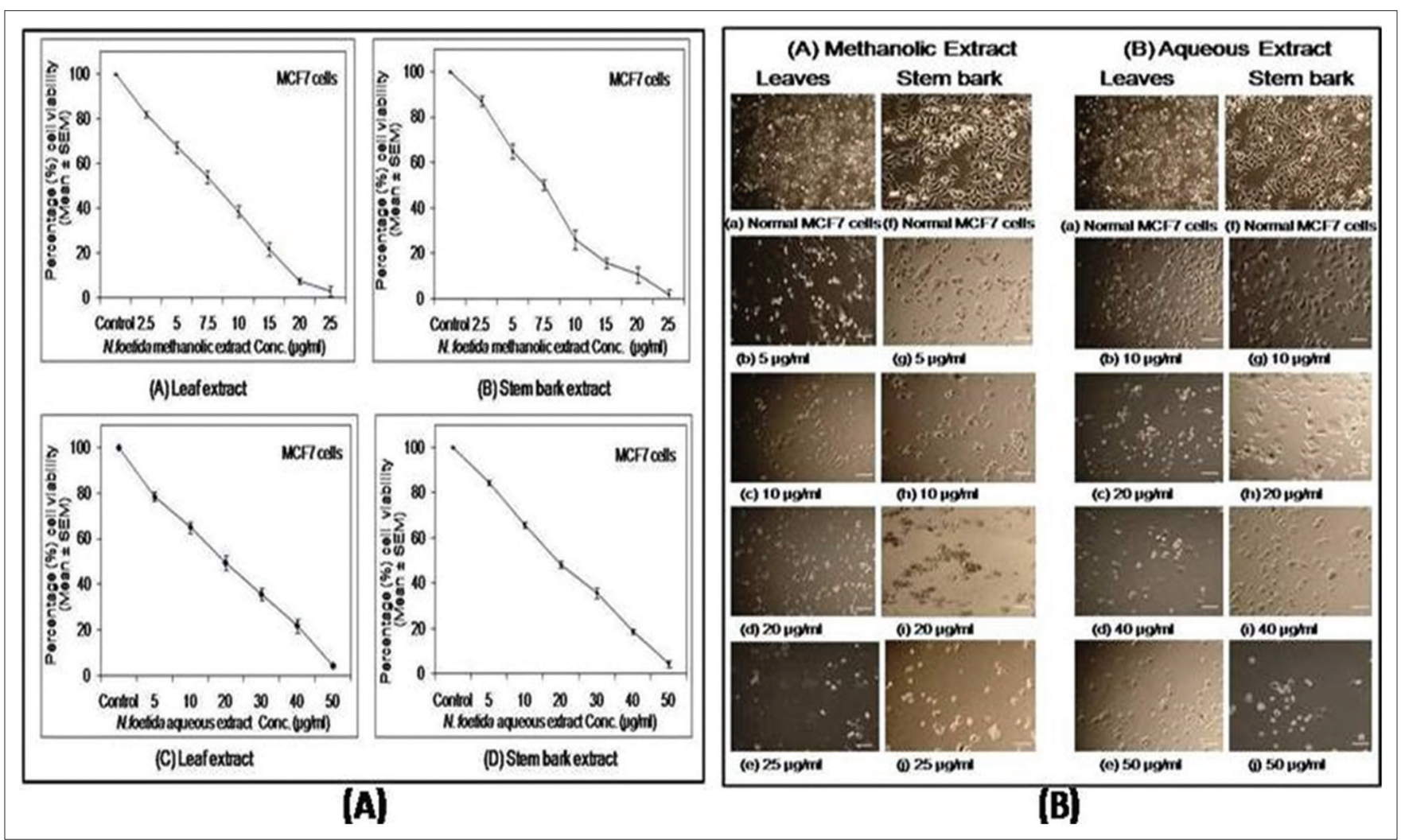

Fig. 2: (A) Representative histogram showing in vitro dose-dependent cytotoxicity of (A) Methanolic extract of leaf (B) Methanolic extract of stem bark (C) Aqueous extract of leaf (D) Aqueous extract of stem bark at different concentrations on MCF7 cells. The results represent the means of three independent experiments, and error bars represent the standard error of the mean. (B) Cell morphology of MCF7 cells after $48 \mathrm{~h}$ treatment of (A) Methanolic extract of leaves and stem bark of Nothapodytes foetida, at different concentrations (b, g) 5, (c, h) 10, (d, i) 20, and (e, j) $25(\mu \mathrm{g} / \mathrm{mL}),(B)$ Aqueous extract of leaves and stem bark at concentrations (b, g) 10, (c, h) 20, (d, i) 40, and $(e, j) 50(\mu \mathrm{g} / \mathrm{mL})$. In all panel, first row of cells $(a, f)$ is untreated control cells. All images are taken at $\times 20$ magnification with Carl Zeiss phase contrast microscope. Scale bars, $100 \mu \mathrm{m}$

whereas $20 \mu \mathrm{g} / \mathrm{mL}$ concentration of methanol extract needed to kill HCT-15 cells. Similarly, $50 \mu \mathrm{g} / \mathrm{mL}$ of aqueous extracts of both leaves and stem bark required to kill Hela and MCF7 cells, whereas HCT15 cells were killed by $40 \mu \mathrm{g} / \mathrm{mL}$ concentration of the aqueous extract of leaves and stem bark. In the present study, $\mathrm{IC}_{50}$ values of methanol extract of $N$. foetida leaves were $7.80 \mu \mathrm{g} / \mathrm{mL}, 8.86 \mu \mathrm{g} / \mathrm{mL}$, and $5.57 \mu \mathrm{g} /$ mL for HeLa, MCF7, and HCT-15 cells, respectively. Furthermore, the $\mathrm{IC}_{50}$ concentrations of methanol extract of stem bark for HeLa, MCF7, and HCT-15 cells were 6.68, 7.57, and $7.52 \mu \mathrm{g} / \mathrm{mL}$, respectively. Simultaneously, the concentrations of aqueous extract of $N$. foetida leaves required to kill $50 \%$ of HeLa, MCF7, and HCT-15 cells are 24.87, 28.62 , and $20.87 \mu \mathrm{g} / \mathrm{mL}$, respectively. The $\mathrm{IC}_{50}$ concentrations of aqueous extract of $N$. foetida stem bark were 21.96, 24.38, and 23.47 for HeLa, MCF7, and HCT-15 cells, respectively, which clearly indicated that both methanol and aqueous extracts of stem bark showed inhibitory effects on the tested MCF7 as well as HeLa cells at lower concentrations than the methanol and aqueous extract of leaves. Based on the observations of sublethal inhibitory concentration (IC), these results indicated that lower concentration of methanol extract of both leaves and stem bark was required to kill HCT-15 cells as compared to HeLa and MCF-7 cells. Similar effects were seen when we tested effect of aqueous extract of leaves and stem bark on the cancer cells, which suggested that HCT-15 cells are more sensitive to both methanol as well as aqueous extract of $N$. foetida than HeLa and MCF-7 cells. Microscopic observations of methanol as well as aqueous extract of leaves and stem bark extract treated HeLa, MCF7, and HCT-15 cells showed distinct cellular morphological alterations such as loss of membrane integrity, therefore, appeared shrunken, cytoplasmic condensation as indicating unhealthy cells, whereas the control cells appeared normal (Fig. 1b, 2b and $3 \mathrm{~b}$ respectively). Based on microscopic observations, the results indicated that when HeLa and MCF-7 cells treated with $25 \mu \mathrm{g} / \mathrm{mL}$ concentration of methanol extract and $50 \mu \mathrm{g} / \mathrm{mL}$ of aqueous extract of leaves and stem bark, all cells were damaged, whereas untreated control cells were intact. HCT-15 cells showed similar effects when exposed to $20 \mu \mathrm{g} / \mathrm{mL}$ concentration of methanol extract and $40 \mu \mathrm{g} / \mathrm{mL}$ concentration of aqueous extract.

Further, we analyzed molecular events such as apoptotic cell death by DNA fragmentation and appearance of expression pattern of apoptotic genes including p53 and caspase-3 at transcriptional as well as translational levels. The DNA fragmentation, considered as one of the hallmarks of cell apoptosis, was confirmed by resolving DNA extracted from HeLa, MCF7, and HCT-15 exposed to $\mathrm{IC}_{50}$ and IC ${ }_{90}$ concentrations of methanol as well as aqueous extracts of both leaves and stem bark on agarose gels. Extensive DNA double-strand breaks appeared in HeLa, MCF7, and HCT-15 cells exposed to plant extracts which serve as powerful evidence of the genotoxic potential of $N$. foetida. Furthermore, to investigate the possible role of p53 and caspase-3 in induction of apoptotic pathway, we examined the levels of p53 and caspase- 3 in $N$. foetida plant extract treated HeLa, MCF7, and HCT-15 cells where both methanol and aqueous extracts of leaves and stem bark increased levels of p53 and caspace- 3 genes in HeLa and HCT-15 cells but did not affect the expression of caspase-3 in MCF7 cell line at mRNA and protein levels. Evaluation of genotoxic effects of $\mathrm{IC}_{50}$ and $\mathrm{IC}_{90}$ concentrations of methanol as well as aqueous extracts of both leaves and stem bark of $N$. foetida on cancer cells including HeLa, MCF7, and HCT-15 cells were assessed by DNA fragmentation pattern on agarose gel. The methanol and aqueous extract of leaves and stem bark were significantly genotoxic to HeLa, MCF7, and HCT-15 cells as noted by extensive double-strand breaks, thereby yielding a ladder appearance 


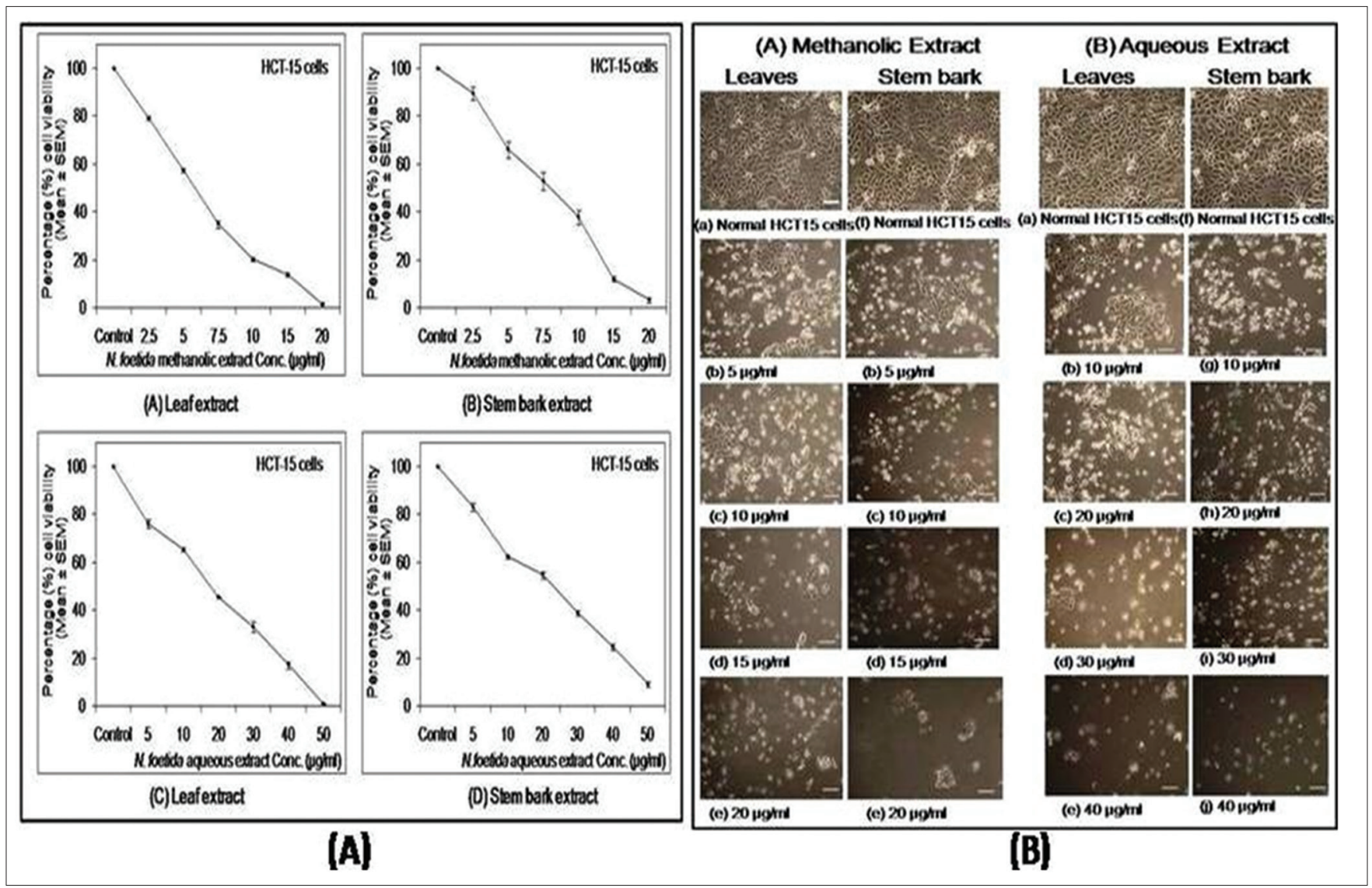

Fig. 3: (A) Representative histogram showing in vitro dose-dependent cytotoxicity of (A) Methanolic extract of leaf (B) Methanolic extract of stem bark (C) Aqueous extract of leaf (D) Aqueous extract of stem bark at different concentrations on HCT-15 cells. The results represent the means of three independent experiments, and error bars represent the standard error of the mean. (B) Cell morphology of HCT-15 cells after $48 \mathrm{~h}$ treatment of (A) Methanolic extract of leaves and stem bark of Nothapodytes foetida, at different concentrations (b, g) 5, (c, h) 10, (d, i) 15, and (e, j) $20(\mu \mathrm{g} / \mathrm{mL})$, (B) Aqueous extract of leaves and stem bark at concentrations (b, g) 10, (c, h) 20, (d, i) 30, and $(e, j) 40(\mu \mathrm{g} / \mathrm{mL})$. In all panel first row of cells $(a, f)$ are untreated control cells. All images are taken at $\times 20$ magnification with Carl

Zeiss phase contrast microscope. Scale bars, $100 \mu \mathrm{m}$

as shown in Lanes 3 and 4 and Fig. 4a and b of HeLa, MCF7 and HCT15 cells, while the DNA of control cells exhibited minimum or no DNA breakage (Lane 2, Fig. 4a and b) of HeLa, MCF7, and HCT-15 cells).

Some of earlier studies hypothesized that possible cytotoxic effect of plant extracts could be because of the presence of various phytochemicals such as alkaloids, flavonoids, tannins, phenolics, and glycosides in stem bark and leaves of N. nimmoniana [13,19-21]. Our results also showed similar trend of response where relatively lower concentrations of both methanol and aqueous extracts of leaves and stem bark are required to kill HeLa, MCF- 7, and HCT-15 cells. In our experiments, the HeLa, MCF7, and HCT-15 cells when treated with both methanol and aqueous extracts for $48 \mathrm{~h}$, the results showed dosedependent cytotoxicity. When we treated the cells with leaves and stem bark extracts, the cells showed remarkable transformations such as cell shrinkage as compared to untreated control cells. Similar cell growth inhibitory effects are comparable to the one reported by Parsaee et al. [22], and Bhatia et al. [23], in other plants, where cytotoxic activity of plant extracts was due to induction of apoptosis through mechanisms involving caspase-3 mediated pathway. Similarly, the extracts of plant parts of Pothos scandens and Caesalpinia sappan significantly showed cytotoxic as well as apoptotic activity against MCF7 breast cancer and HT29 colon carcinoma cell line $[24,25]$.

Results of semiquantitative RT-PCR analysis for mRNA level expression of apoptotic genes are shown in Fig. $5 \mathrm{a}-\mathrm{f}$ ). Methanol as well as aqueous extracts of $N$. foetida leaves and stem bark significantly $(\mathrm{p}<0.001)$ increased expression of p53 in HeLa, MCF7 as well as HCT-15cells when treated at $\mathrm{IC}_{50}$ concentration. Caspase- 3 was significantly upregulated $(\mathrm{p}<0.001)$ in HeLa as well as HCT-15 cells when treated with both methanol and aqueous extract of leaves and stem bark at IC concentration as compared to unexposed control cells except MCF7 cells which showed comparatively lower levels of expression $(p<0.05)$. We also determined the protein level expression of selected apoptotic genes by western blotting. The expression of p53 was observed to be significantly higher $(\mathrm{p}<0.001)$ in HeLa, MCF7, as well as HCT-15 cells (Fig. 6a-f). Evaluation of caspase-3 showed higher levels of the protein in HeLa, and HCT-15 cells $(p<0.001)$ when treated both methanol and aqueous extract of both leaves and stem bark compared to untreated cells, whereas MCF7 cells did not show significant difference in levels of expression of caspase-3 (p<0.05) (Fig. 6c-d). Similar inhibitory and apoptosis inductive effects of phytochemicals were observed earlier [26-28]. Thus, our study provides plausible evidence supporting strong apoptotic potential of $N$. foetida plant extract against selected cancer cells.

\section{CONCLUSION}

These results indicated that the crude plant extract of $N$. foetida has a potential as cytotoxic agent against cancer cells. Methanol extract of stem bark as well as leaves was more effective than aqueous extracts probably due to a higher yield of the phytoconstituents during extraction. Based on $\mathrm{IC}_{50}$ values of both the aqueous and methanol extracts, lower concentrations of methanol extracts of leaves and stem bark are required to kill cells. The probable cell death in tested cells exposed to plant extracts was induced through apoptotic pathway. However, further studies need 



Fig. 4: Representative agarose gel images showing DNA fragmentation in cancer cells treated with leaf extract (upper panel) and stem bark extract (lower panel) of Nothapodytes foetida at IC ${ }_{50}$ and IC ${ }_{90}$ concentrations. Left panel (A) showing DNA fragmentation pattern of HeLa, MCF7, and HCT-15 cells treated with methanolic extracts (B) and aqueous extracts of leaves and stem bark. In each representative gel, Lane 1 is 100 bp DNA marker, Lane 2 is DNA from control cells followed by Lane 3: DNA from IC ${ }_{50}$ concentration treated cells, Lane 4: DNA from $\mathrm{IC}_{90}$ treated cells, and Lane 5 is $1 \mathrm{~Kb}$ DNA marker

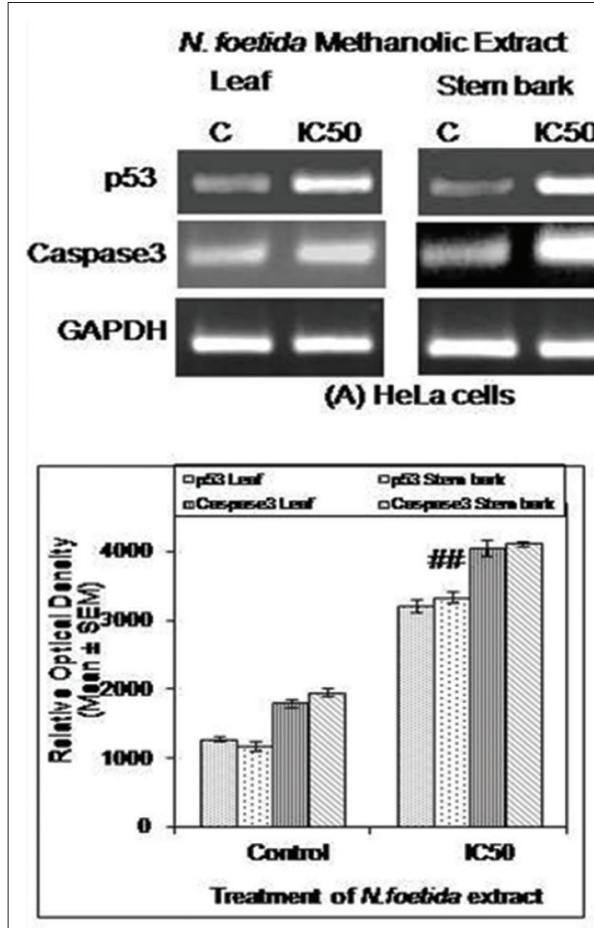

(B) mRNA expression in HeLa cells

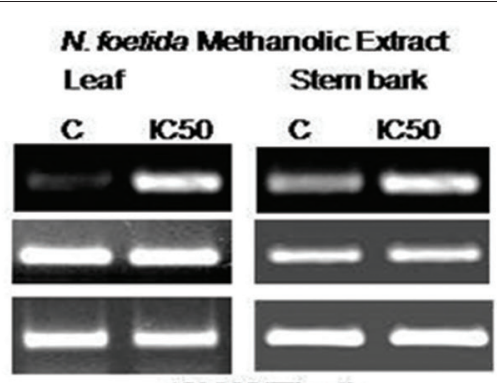

(C) MCF7 cells

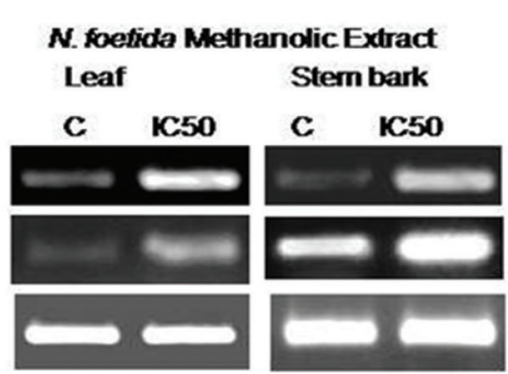

(E) HCT-15 cells

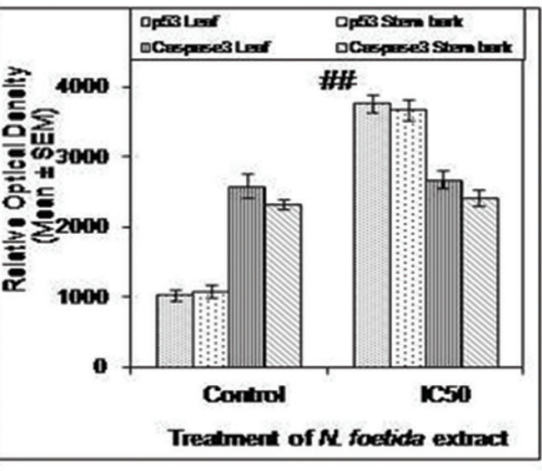

(D) mRNAexpression in MCF7cells



(F) mRNA expression in HCT-15 cells

Fig. 5: Representative semiquantitative reverse transcription-polymerase chain reaction image showing expression of $P 53$, caspase-3m and GAPDH genes from (A) HeLa, (C) MCF7, and (E) HCT-15 cells exposed to IC ${ }_{50}$ concentration of methanolic extracts of leaves and stem

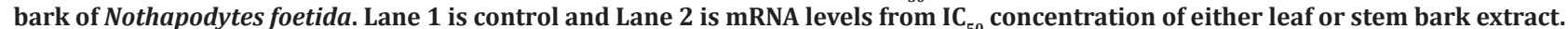
Relative levels of p53 and Caspase-3 cDNA of (B) HeLa (D) MCF7, and (F) HCT-15 cells quantified by densitometry. Error bars indicate the standard error of the mean for three independent experiments $(n=3)$. Significant differences in mRNA expression between control and methanolic extracts of leaf and stem bark extract of $N$. foetida exposed samples assessed by Student's t-test are indicated; (\#\# $\mathbf{p}<0.001)$ which found to be increased significantly in samples obtained from IC $\mathrm{C}_{50}$ concentration treatment as compared to control 


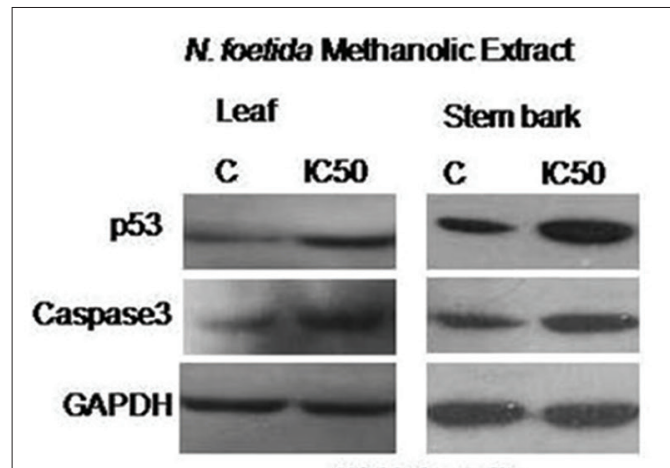

(A) HeLa cells

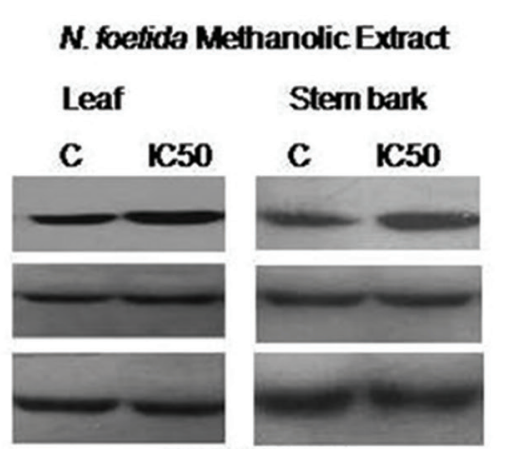

(C) MCF7 cells

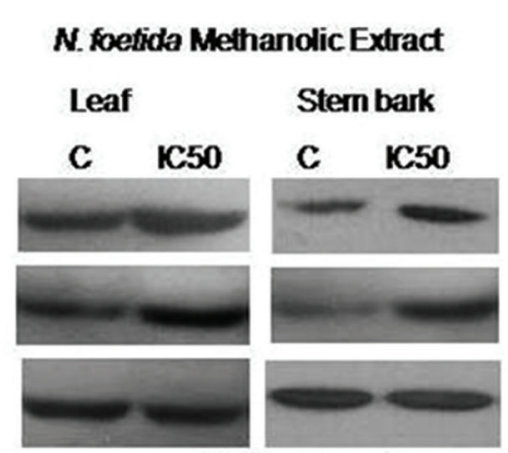

(E) HCT-15 cells

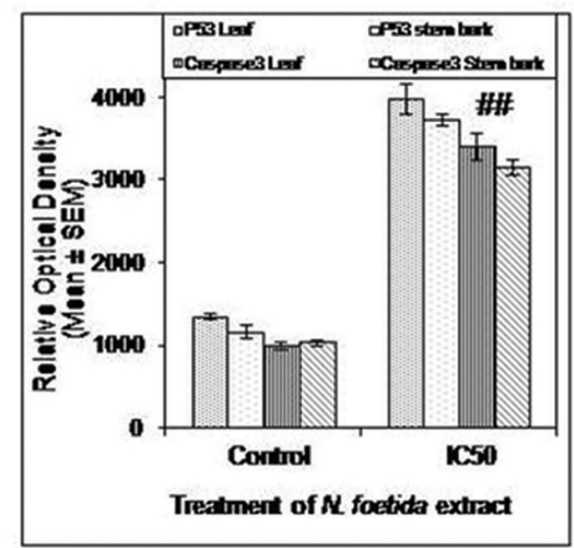

(B) Protein expression in HeLa cells

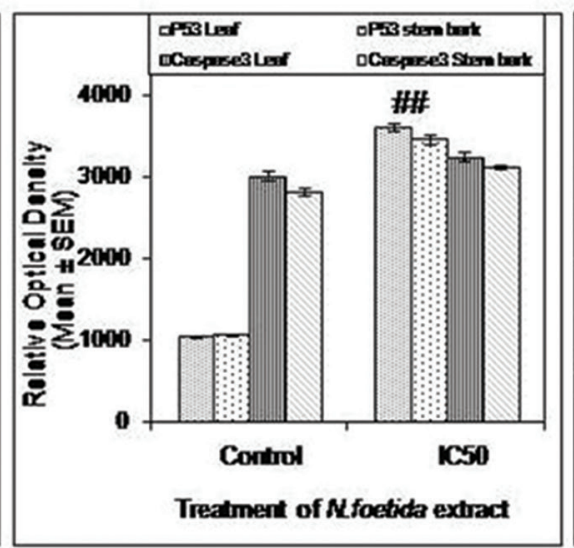

(D) Protein expression in MCF7 cells



(F) Protein expression HCT-15 cells

Fig. 6: Representative western blot showing expression of P53 and Caspase-3 protein form (A) HeLa (C) MCF7, and (E) HCT-15 cells exposed to $\mathrm{IC}_{50}$ concentration of methanolic extract of leaves and stem bark of Nothapodytes foetida. Lane 1 is control; Lane 2 is cell protein extracts from $\mathrm{IC}_{50}$ concentration treated cells. Levels of apoptotic proteins were adjusted with GAPDH (loading control) examined by specific antibodies. (B) Histogram showing relative levels of P53 and Caspase3 proteins of (B) HeLa, (D) MCF7, and (F) HCT-15 cells quantitated by densitometric analysis. Error bars indicate the standard error of the mean for three independent experiments ( $n=3$ ). Significant differences in levels of protein expression between control and methanol extract of leaves and stem bark of $N$. foetida treated samples were assessed by Student's t-test are indicated $(\# p<0.001)$ which are found to be increased significantly in samples obtained from IC ${ }_{50}$ concentration treated cells as compared to control.

to be carried out to understand the detailed molecular mechanism in the presence of well-characterized active principles derived from $N$. foetida.

\section{ACKNOWLEDGMENTS}

The authors gratefully acknowledge all the facilities and financial support provided by the Krishna Institute of Medical Sciences "Deemed to be University," Karad, India, for experimental work. Authors are thankful to Mr. Santosh Jadhav for technical support.

\section{AUTHORS' CONTRIBUTIONS}

KD; Concept design, analysis of results, and manuscript preparation; PD and MP: Experimental work.

\section{CONFLICTS OF INTEREST}

The authors declare no conflicts of interest.

\section{FINANCIAL SUPPORT AND SPONSORSHIP}

Nil.

\section{REFERENCES}

1. Solowey E, Lichtenstein M, Sallon S, Paavilainen H, Solowey E, Lorberboum-Galski $\mathrm{H}$, et al. Evaluating medicinal plants for anticancer activity. Sci World J 2014;2014:721402.

2. Greenwell M, Rahman PK. Medicinal plants: Their use in anticancer treatment. Int J Pharm Sci Res 2015;6:4103-12.

3. Moiseeva EP, Manson MM. Dietary chemopreventive phytochemicals: Too little or too much? Cancer Prev Res (Phila) 2009;2:611-6.

4. Gullett NP, Ruhul Amin AR, Bayraktar S, Pezzuto JM, Shin DM, Khuri FR, et al. Cancer prevention with natural compounds. Semin Oncol 2010;37:258-81

5. Mehta RG, Murillo G, Naithani R, Peng X. Cancer chemoprevention by natural products: How far have we come? Pharm Res 2010;27:950-61.

6. Singh I, Kumaravadivel N, Gnanam R, Vellaikumar S. RP-HPLC analysis for camptothecin content in Nothapodytes nimmoniana, an endangered medicinal Plant. J Med Plants Res 2010;4:255-9.

7. Kavitha P, Vasanthakumar T, Rajshekharan PE, Kareem VK, Rao VK. Camptothecin and 9-methoxy camptothecin, anti-cancer alkaloids in Nothapodytes nimmoniana from Western Ghats, India. J Med Aromat Plant Sci 2010;32:129-32.

8. Namdeo AG, Sharma A. HPLC analysis of camptothecin content in various parts of Nothapodytes foetida collected on different periods. Asian Pac J Trop Biomed 2012;2:389-93.

9. Hsiao HY, Cheng TJ, Yang GM, Huang IJ, Chen RL. Determination of camptothecins in DMSO extracts of Nothapodytes foetida by direct injection capillary electrophoresis. Phytochem Anal 2008;19:136-40.

10. Liao N, Zhang P, Ao M, Wang J, Shi Y, Yu L, et al 9-methoxycamptothecin from Nothapodytes foetida induces apoptosis in murine sarcoma S180 cells. Z Naturforsch C 2011;66:471-6.

11. Premalakshmi V, Chitra AD, Theradimani M. Effect of camptothecin a potent anti cancer drug from Mappia foetida on breast cancer cell line MDA-MB-231. J Med Plant Res 2012;6:5522-6.

12. Sharma A, Namdeo AG, Mahadik KR. Pharmacognostic studies on Nothapodytes nimmoniana. Int J Pharma Res Dev 2009;1:1-10. 
13. Sharma S, Kumar A, Namdeo AG. Pharmocognostical and phytochemical analysis of Nothapodytes nimmoniana stem. Int J Pharm Pharm Sci 2012;4:455-9.

14. Uma G, Balasubramaniam V, Jagathes K. Evaluation of antimicrobial activity of Nothapodytes nimmoniana (Graham) Icacianaceae. W J Pharm Pharm Sci 2013;2:5078-83.

15. Khan N, Tamboli ET, Sharma VK, Kumar S. Phytochemical and pharmacological aspects of Nothapodytes nimmoniana. An overview. Herba Pol 2013;59:53-6.

16. Mahendran G, Kumari BD. Biological activities of silver nanoparticles from Nothapodytes nimmoniana (Graham) Mabb. Fruit extracts. Food Sci H Well 2016;5:207-18.

17. Datkhile KD, Durgawale PP, Patil MN, Vavhal RD, Khamkar TS. Evaluation of in vitro antioxidant and free radical scavenging properties of different parts of medicinal plant Nothapodytes foetida (Family: Icacinaceaae). Int J Sci Res 2016;5:80-4.

18. Datkhile KD, Durgawale PP, Patil MN. Biogenic silver nanoparticles from Nothapodytes foetida kills human cancer cells in vitro through inhibition of cell proliferation and induction of apoptosis. J Bionanosci 2017;11:416-27.

19. Khan N, Kumar S, Singh RP, Ghankhar N. Preliminary phytochemical screening, fingerprinting and pharmacognostic evaluation of Nothapodytes nimmoniana leaves, stem and root collected from different geographical region. Res J Pharm Biol Chem Sci 2012a;3:362-78.

20. Khan N, Kumar S, Singh RP, Ghankhar N. Anthelmintic activity in root of Nothapodytes nimmoniana in different extracts. Int J Res Pharm Biomed Sci 2012b;3:31-3.

21. Dixit A, Gayakwas S, Shirodkar A, Warkad S, Devlae A, Murthy S, et al. Phytochemical characterization and cells based analysis of bioactive components of Nothapodytes nimmoniana (J. Graham). Int J curr Microbiol App Sci 2015;2:18-37.

22. Parsaee H, Asili J, Mousavi SH, Soofi H, Emami SA, TayaraniNajaran Z, et al. Apoptosis induction of Salvia chorassanica root extract on human cervical cancer cell line. Iran J Pharm Res 2013;12:75-83.

23. Bhatia D, Mandal A, Nevo E, Bishayee A. Apoptosis-inducing effects of extracts from desert plants in HepG2 human hepatocarcinoma cells. Asian Pac J Trop Biomed 2015;5:87-92.

24. Verdam MC, Guilhon-Simplicio F, Paula CD, De Oliveira VB, Miguel MD, Stuelp-Campelo PM, et al. Cytotoxicity of Byrsonima duckeana W. R. Anderson (Malpighiaceae) on colon cancer cells. Int J Pharm Pharm Sci 2014;6:509-10.

25. Jethinlalkhosh JP, Nair SS, Praveena P, Doss VA. Cytotoxicity and apoptotic inducibility of hydro-ethanolic extract of aerial parts of Pothos scandens L. Against mcf-7 breast cancer cell line. Int J Pharm Pharm Sci 2016;8:274-6.

26. Machana S, Weerapreeyakul N, Barusrux S, Nonpunya A, Sripanidkulchai B, Thitimetharoch $\mathrm{T}$, et al. Cytotoxic and apoptotic effects of six herbal plants against the human hepatocarcinoma (HepG2) cell line. Chin Med 2011;6:39.

27. Maliyakaal N, Udupa N, Pai KS, Rangarajan A. Cytotoxic and apoptotic activities of extracts of Withania somnifera and Tinospora cordifolia in human breast cancer cells. Int J Appl Res Nat Prod 2013;6:1-10.

28. Bhatia D, Thoppil RJ, Mandal A, Samtani KA, Darvesh AS, Bishayee A. Pomegranate bioactive constituents suppress cell proliferation and induce apoptosis in an experimental model of hepatocellular carcinoma: Role of Wnt $/ \beta$-catenin signaling pathway. Evid Based Complement Alternat Med 2013;2013:371813. 